\title{
Remaja dan Pendidikan Seks
}

\author{
Ade Marta Putra, M.Pd.
}

STKIP Muhammadiyah Muara Bungo - ademartaputra1@gmail.com

\begin{abstract}
Abstrak
Pendidikan seks dipandang oleh remaja sebagaisesuatu hal yang menarik, bernilai positif, serta bermanfaat bagi mereka dalammembantu persoalan hidup remaja. Melalui pendidikan seks remaja mampumengarahkan perilaku seksualnya agar tidak menyimpang dari norma yang adaserta dapat terhindar dari hal-hal yang negatif. Dengan kata lain remajamemandang pendidikan seks sebagai alat untuk mencegah terjadinyapenyalahgunaan seks. Remaja menganggap pendidikan seks mampu menjawabkeingintahuan dan rasa penasaran mereka akan segala hal yang berkaitan denganseks. Oleh karena itu remaja menganggap pendidikan seks sebagai suatukebutuhan dan mereka tidak tabu. Sumber pendidikan seks yangdigunakan oleh remaja adalah media massa baik media cetak seperti koran,majalah, dan buku maupun media elektronik seperti televisi dan internet sertateman sebaya atau peer group. Remaja banyak mendapatkan informasi dan pengetahuan seks dari media massa dan teman sebaya karena sumber pendidikantersebut dapat memberikan transparan pada mereka. Pendidikan seks justru tidak didapat remaja dari lingkungan keluarga ataupun sekolah. Pengetahuan seputar seks yang dicari dan dibutuhkan oleh remaja adalah pengetahuan tentang HIV AIDS, menstruasi, penyakit kelamin, dampak atau resiko melakukan seks bebas, proses reproduksi atau hubungan seks dan gaya pacaran sehat.
\end{abstract}

\section{PENDAHULUAN}

Semakin cepat laju perkembangan teknologi serta informasi mendorong masyarakat terintegrasi ke dalam satu sistem dunia (sexual permissive), perilaku agresif mengglobal dan universal. Perubahan dalam (aggressiveness), konsumerisme dan sekularisme. masyarakat pada seluruh aspek kehidupan sudah (Jalaludin dalam Idi Subandi Ibrahim, 1997: 39). tidak dapat terelakkan lagi. Perubahan yang Bahkan perkembangan teknologi mengakibatkan terjadi disadari memberikan kemajuan yang semakin terbukanya arus informasi yang sangat pesat di berbagai sektor. Salah satunya, mengandung seks di tengah-tengah masyarakat penemuan dalam bidang teknologi menjadikan dunia semakin mudah untuk akses oleh siapapun, di manapun dan kapanpun. Informasi menjadi kebutuhan yang penting di masa ini. Informasi dapat segera di akses melalui internet ataupun pemberitaan di berbagai media massa. Namun seiring terjadinya globalisasi serta kemajuan teknologi dan informasi tidak dipungkiri turut serta mengubah perilaku sosial di kalangangenerasi muda dan persepsi individu terhadap nilai dari luar. Nilai-nilai peradaban barat dengan cepat menyebar ke negara-negara "A berkembang. Salah satu bentuk ketegangan dan kemelut yang terjadi akibat penetrasi media mas adalah hancurnya nilai-nilai tradisional dan merembesnya nilai-nilai modernitas yang destruktif.
Media informasi yang mutakhir sarat dengan pesan-pesan yang mendorong ibahan seksual semakin terbukanya arus informasi yang
mengandung seks di tengah-tengah masyarakat

Pemberbicara tentang seks di media baik cetak maupun elektronik) serta kemudahan dalam mengaksesnya (seperti melalui website di internet, VCD porno, film dewasa, akses situs porno di handphone dan cara lainny. Seks menjadi bagian yang penting dan selalu diadopsi oleh teknologi baru (Brooks dalam Goldberg, 2004). mengakibatnya remaja mendapatkan informasi tentang seksualitas lebih dini dari generasi sebelumnya. Seperti yang diungkapkan oleh psikolog Elizabeth Hurlock (2000: 135): "Anak-anak masa kini tidak luput dari banjir seks di media massa, semua banjir seks di media massa; semua bentuk media massa, misalnya komik, film, televisi, dan surat kabar, menyuguhkan gambar dan informasi tentang seks yang meningkatkan minat anak. Pertunjukan film 
dan televisi yang "untuk tujuh belas tahun ke atas" atau hanya di bawah bimbingan orang tua" makin memperbesar minat anak pada seks".

Berbicara tentang pendidikan seks tentunya tidak akan terlepas dengan pemahaman seseorang terhadap apa dan bagaimana pendidikan seks itu

Menghadapi tantangan globalisasi dan sendiri. Perbedaan pemahaman tentang perkembangan ilmu pengetahuan dan teknologi pendidikan seks ini tergantung pada bagaimana diperlukan adanya sumber daya manusia yang sudut pandang yang mereka gunakan dalam berkualitas. Remaja merupakan bagian dari memberikan definisi tersebut. Pendidikan seks sumber daya manusia serta masa depan bangsa. sebenarnya berarti pendidikan seksualitas, yaitu Sebagai generasi penerus bangsa, remaja akan suatu pendidikan mengenai seksualitas dalam arti berperan penting dalam melanjutkan luas. Seksualitas meliputi berbagai aspek yang pembangunan bangsa Indonesia serta mempunyai berkaitan dengan seks, yaitu aspek biologis, andil besar dalam menentukan nasib bangsa. Pendidikan seks bukanlah berarti belajar tentang Remaja diharapkan memiliki moral dan rasa bagaimana berhubungan seksual, seperti yang tanggung jawab yang tinggi. Jumlah remaja dianggap banyak orang sehingga bentuk sangat besar merupakan potensi sumber daya pendidikan ini seolah dilarang karena dianggap manusia yang sangat berharga apabila dapat bisa berekses buruk pada remaja. Pendidikan seks dibina dengan baik. Sebaliknya potensi yang merupakan sebuah diskusi yang realistis, jujur, besar tersebut apabila tidak dibina dengan baik, dan terbuka bukan merupakan dikte moral akan menimbulkan berbagai persoalan serius belaka. Dalam pendidikan seks diberikan seperti yang terjadi saat ini. Persoalan tersebut pengetahuan yang faktual, menempatkan seks antara lain penyalahgunaan narkotika, kenakalan pada perspektif yang tepat, berhubungan dengan remaja, dan termasuk persoalan yang berkaitan self-esteem (rasa penghargaan terhadap diri), dengan aktivitas seksual, seperti seperti penanaman rasa percaya diri dan difokuskan pada pelecehan dan kekerasan seksual, hubungan peningkatan kemampuan dalam mengambil seksual pra nikah, KTD (Kehamilan Tidak keputusan.

Dikehendaki), aborsi, pernikahan di usia muda, PMS (Penyakit Menular Seksual) termasuk HIV/AIDS serta permasalahan sosial lainnya yang sangat berpengaruh terhadap kesiapan remaja untuk menyongsong masa depan. Masa remaja merupakan suatu fase perkembangan dari masa kanak-kanak menuju ke arah kedewasaan. Di samping remaja adalah manusia yang sedang berkembang secara fisik dan psikologis (emosi). Dalam keadaan seperti itu berkembang pula fungsi-fungsi hormonal dalam tubuh remaja. Umumnya proses kematangan fisik lebih cepat terjadi dari pada proses kematangan psikologis. Melihat masa remaja sangat potensial dan dapat berkembang ke arah positif maupun negatif maka intervensi edukatif dalam bentuk pendidikan, bimbingan, maupun pendampingan sangat diperlukan untuk mengarahkan potensi remaja tersebut agar berkembang dengan baik, ke arah positif dan produktif. Sehubungan dengan ini, masalah seks remaja sesungguhnya merupakan masalah yang sangat penting dan harus segera diantisipasi.

Pendidikan seks diperlukan untuk menjembatani antara rasa keingintahuan remaja kelamin. tentang hal itu dan berbagai tawaran informasi berbicara tentang seks sebenarnya tidak hanya yang vulgar, dengan cara pemberian informasi membicarakan tentang hubungan seksual dan haltentang seksualitas yang benar, jujur, lengkap, hal negatif seperti halnya anggapan mereka yang disesuaikan dengan kematangan usianya. selama ini. Berbicara seks artinya kita 
membicarakan tentang kesehatan reproduksi, kenikmatan. Efek dari melakukan aktivitas anatomi, fisiologi organ reproduksi, penyakit seksual dirasakan dapat memberikan kepuasan menular seks dan lain-lain. Definisi seks juga dan kenikmatan tersendiri bagi pelakunya.

bisa dilihat dari beberapa dimensi di antaranya Biasanya kata "seks" menjadi pangkal seperti biologis, psikologis, medis, dan sosial. perdebatan dalam pendidikan seks. Padahal, kata Kata seks umumnya sudah tidak asing lagi di seks itu mempunyai arti jenis kelamin yang telinga para remaja karena mereka sering memberi kita pengetahuan tentang sesuatu sifat menerima berbagai informasi tentang seks dari atau ciri yang membedakan antara jenis lakilaki media massa seperti televisi, internet, dan dengan perempuan. Dunia remaja adalah dunia majalah. Pandangan remaja tentang seks sendiri yang khas. Remaja memahami lingkungan tidak jauh berbeda dengan pandangan masyarakat sekitarnya dengan cara yang berbeda dengan pada umumnya. Dari hasil wawancara, beberapa cara-cara yang dilakukan oleh orang dewasa dan informan memberikan argumen yang serupa, anak-anak. Dunia luar diinterpretasi seorang sebagian besar mengatakan ketika mendengar remaja dengan nilai-nilai yang masih berada di kata seks biasanya pikiran mereka langsung tertuju pada hubungan intim atau hubungan kelamin.

dalam tahap perkembangan dan rasa ingin tahu yang besar. Pola yang sama juga terjadi ketika remaja mempersepsikan pendidikan seks. Dalam

Kata seks selalu diasosiasikan oleh remaja memandang suatu permasalahan setiap orang dengan hubungan badan. Ketika remaja mempunyai persepsi yang berbeda-beda, begitu mendengar kata seks pikiran mereka langsung halnya dengan remaja. Persepsi seseorang tertuju pada aktivitas seksual atau hubungan berkaitan dengan pengalaman, kemampuan badan. Padahal, hubungan seks hanyalah salah maupun daya persepsi yang diterimanya. Persepsi satu bagian dari cakupan istilah seks yang begitu adalah pengalaman tentang objek, peristiwa, atau luas. Remaja selalu mengasosikan seks dengan hubungan-hubungan yang diperoleh dengan aktivitas seksual atau hubungan badan. Hal ini ini menyimpulkan informasi dan menafsirkan pesan, tidaklah mengherankan karena pada dasarnya keinginan, sikap dan tujuan kita (Jalaludin dalam konteks masyarakat kita seks hanya Rakhmat, 2007: 51).

diartikan dengan hubungan badan semata. Pendidikan seks seringkali menimbulkan Berdasarkan pemahaman remaja, seks identik kontroversi di tengah-tengah masyarakat. dengan hubungan badan. Pada umunya remaja Pandangan pro dan kontra pendidikan seks ini beranggapan bahwa seks adalah hubungan badan pada hakikatnya tergantung sekali pada atau hubungan badan sama dengan seks.

bagaimana kita mendefinisikan pendidikan seks

Pemahaman remaja terhadap seks sangat itu sendiri. Jika pendidikan seks diartikan sebagai sempit karena mengidentikan seks dengan belajar tentang berhubungan badan atau aktivitas hubungan badan. Begitu sempitnya pemahaman seksual dan berbagai cara atau teknik untuk mereka sehingga ketika orang membicarakan melakukannya, maka kecemasan tersebut diatas tentang seks yang ada di dalam pikirannya adalah memang beralasan.

hanyalah aktivitas seksual, hubungan badan. Padahal, hubungan seks hanyalah salah satu bagian dari cakupan istilah seks yang begitu luas. Pernyataan-pernyataan tersebut semakin menunjukkan kalau makna seks telah mengalami pereduksian makna, seks disempitkan hanya pada aspek fisik, dikaitkan dengan segala sesuatu yang menyangkut aktivitas berhubungan badan. Dalam istilah kesehariannya, kata seks lebih sering mereka artikan bukan pada arti yang sebenarnya yaitu jenis kelamin melainkan identik dengan hubungan kelamin. Hal ini terutama disebabkan oleh terbatasnya pengetahuan tentang seks yang dimiliki oleh remaja sehingga mengakibatkan kurangnya pemahaman yang benar mengenai arti seks yang sesungguhnya. Seks dipandang sebagai sesuatu yang dapat mendatangkan kepuasan dan

Pendidikan seks dipandang dapat memberikan pemahaman yang benar mengenai seks. Pendidikan seks adalah suatu usaha yang berupaya untuk membekali seseorang dengan pengetahuan tentang seks. Tujuannya adalah membuat seseorang menjadi paham tentang seks sehingga dapat menempatkan seks pada perspektif yang baik dan benar serta mengubah anggapan yang keliru dan negatif mengenai seks. Tujuan lain dari pendidikan seks adalah dapat mengarahkan individu untuk berperilaku positif dan menghindarkan diri dari penyalahgunaan seks. Tujuan pendidikan seks pada dasarnya adalah untuk memenuhi kebutuhan informasi individu akan seks secara jelas dan benar sehingga mereka dapat menempatkan seks pada perspektif yang tepat. Hal yang demikian inilah 
yang dapat ditangkap dari jawaban ketiganya. kebutuhan jadi hal tersebut harus dipenuhi agar Kembali konsep pemahaman yang mengemuka nantinya remaja tidak berusaha untuk mencari dalam hal ini, bahwa pemahaman remaja tahu informasi dari sumber-sumber yang kurang mengenai pendidikan seks dipahami sebagai dapat dipercaya kebenarannya.

suatu bentuk usaha yang berupaya membekali Dunia remaja adalah dunia yang khas, seseorang dengan segala pengetahuan tentang remaja selalu mempunyai rasa keingintahuan seks sehingga akan meyebabkan seseorang terhadap segala sesuatu, tak terkecuali tentang menjadi tahu tentang seks.

seks. Begitu halnya dengan dorongan seksual

Pendidikan seks tidak hanya dipandang yang ada pada diri remaja, rasa ketertarikan sebagai suasana pemberian informasi dan terhadap lawan jenis juga telah dirasakan remaja, pengetahuan tentang seks saja, namun juga sehingga banyak diantara mereka yang sudah diperluas sehingga mencakup usaha untuk mengenal aktivitas seperti pacaran. Tentunya mewujudkan keinginan, kebutuhan dan remaja butuh pendidikan seks agar mereka dapat kemampuan individu sehigga tercapai pola hidup mengarahkan dan mengendalikan perilaku pribadi dan sosial yang memuaskan. Pendidikan seksualnya. Pendidikan seks sangat diperlukan bukan semata-mata sarana untuk persiapan remaja dan merupakan bagian dari kebutuhan kehidupan yang akan datang, tetapi juga hidup mereka sehingga pendidikan seks dinilai kehidupan anak sekarang yang sedang sebagai hal yang baik.

mengalami perkembangan menuju tingkat Dengan diberikannya pendidikan seks kedewasaannya. Memahami seks secara positif sehingga dapat menjadikan remaja mengetahui bukan berarti menginginkan untuk melakukan dan memahami tentang seks itu sendiri, tidak hubungan seksual tetapi lebih pada bagaimana hanya itu saja pendidikan seks dapat memberikan mempunyai pemahaman dan sikap positif banyak manfaat bagi mereka. Dengan demikian terhadap seks yang melekat pada diri kita sendiri remaja memandang pendidikan seks sebagai hal

Pendidikan seks disebut sebagai sebuah yang baik dan positif. Adapun alasan-alasan yang kebutuhan karena melalui pendidikan seks mendasari remaja membutuhkan pendidikan seks diharapkan mampu memberikan pengetahuan dan salah satunya adalah supaya tidak terjerumus ke informasi yang luas, jelas dan benar mengenai dalam pergaulan yang bebas, terhindar dari halsegala hal yang berkaiatn dengan seks. hal yang negatif dalam kaitannya dengan Pendidikan apapun bentuknya dan sifatnya penyalahgunaan aktivitas seksual. Meskipun merupakan sebuah kebutuhan bagi individu, masih ada anggapan dalam masyarakat bahwa sama halnya dengan pendidikan seks. Oleh membicarakan segala hal yang berkaitan dengan karena pendidikan seks dipandang sebagai seks adalah hal yang tabu sehingga pendidikan sebuah kebutuhan sehingga jelas harus dapat seks sering tidak terimplementasikan dengan terpenuhi dengan baik. Remaja mengaku butuh baik. Akan tetapi lain halnya dengan anggapan pendidikan seks agar dapat mengetahui perpektif remaja. Dari hasil wawancara, didapatkan bahwa seks secara jelas dan benar. Pada dasarnya pada umumnya remaja tidak menganggap pendidikan seks dibutuhkan oleh remaja karena pendidikan seks sebagai hal yang tabu atau tidak mereka memang sudah ada pada masanya untuk patut untuk dibicarakan. Pendidikan seks justru mengetahui segala sesuatu yang berkaitan dengan dianggap perlu dan penting untuk diberikan pada seks. Remaja sudah tidak lagi dikategorikan remaja agar dapat membantu mengatasi setiap sebagai anak-anak akan tetapi belum juga persoalan seks remaja.

termasuk sebagai orang dewasa. Sejalan dengan Pendidikan seks dalam pelaksanaannya hal itu remaja membutuhkan pengarahan dan mempunyai maksud dan tujuan tertentu. Salah bimbingan dari pihak lain, termasuk juga dibekali satu adalah sebagai alat pengendali atau dengan segala pengetahuan tentang seks agar pencegah terjadinya penyalahgunaan seks. Hal dapat membantu remaja dalam mengatasi setiap ini juga tidak dipungkiri oleh remaja. Pendidikan permasalahan remaja yang berkaitan dengan seks dianggap oleh remaja sebagai upaya perilaku seksualnya. Pada dasarnya remaja preventif karena dapat menghindarkan seseorang membutuhkan pendidikan seks hal ini karena dari aktivitas penyalahgunaan seks. Pendidikan mereka sudah berada pada masanya untuk seks di samping bertujuan untuk menghindarkan mengetahui segala sesuatu yang berkaitan dengan seeorang dari segala bentuk penyalahgunaan seks seks sehingga pendidikan seks merupakan suatu juga dianggap dapat mengarahkan dan kebutuhan bagi remaja. Karena merupakan suatu mengendalikan seseorang agar berperilaku positif 
dan tidak terjerumus ke dalam hal-hal yang faktor lingkungan di mana persepsi itu negatif. Dengan kata lain, pendidikan seks dapat berlangsung. Persepsi remaja tentang pendidikan menjadikan seseorang untuk berperilaku positif. seks diantaranya adalah pendidikan seks

Pendidikan seks dapat menghindarkan dipandang oleh remaja sebagai sesuatu yang remaja pada perilaku negatif seperti melakukan urgen atau penting, mempunyai nilai positif, baik, seks pra nikah dan mengarahkan remaja pada dan bermanfaat dalam membantu setiap gaya pacaran yang sehat. Ini adalah salah satu persoalan hidup remaja. Pendidikan seks segi positif dari pendidikan seks. Meskipun tidak dianggap dapat menjawab semua rasa penasaran dipungkiri ada juga pikiran negatif tentang dan keingintahuan remaja terhadap seks, dapat pendidikan seks seperti pendidikan seks dapat mengarahkan remaja untuk berperilaku baik dan mendorong seseorang untuk melakukan aktivitas benar sehingga terhindar dari hal-hal yang negatif seksual. Sejalan dengan perkembangannya dan merugikan bagi diri remaja sendiri, dianggap remaja mempunyai dorongan rasa ingin tahu sebagai alat untuk mencegah terjadinya terhadap segala sesuatu yang menyangkut penyalahgunaan seks, dianggap sebagai suatu keadaan diri, tak terkecuali tentang seks. Seks kebutuhan karena dapat membantu remaja dalam dinilai eksklusif oleh remaja, artinya selalu ada mengatasi setiap persoalan hidup yang ada rasa ingin tahu yang besar terhadap seks. kaitannya dengan seks, juga dipandang bukan Pendidikan seks dipandang oleh dapat menjawab sebagai hal yang tabu oleh remaja karena rasa keingintahuan dan penasaran remaja tentang pendidikan seks memang sangat diperlukan seks.

Pada dasarnya pendidikan seks berupaya untuk menjawab segala keingintahuan dan rasa penasaran remaja tentang seks dengan memberikan pemahaman seks secara jelas dan benar. Pendidikan seks diartikan sebagai sebagai semua cara pendidikan yang dapat membantu anak muda untuk menghadapi persoalan hidup yang berpusat pada naluri seks, yang kadangkadang timbul dalam bentuk tertentu dan merupakan pengalaman manusia yang normal (Warnaen dalam Sri Esti Wuryani). Pendidikan seks dinilai sebagai suatu hal yang sifatnya urgen, baik dan positif dan sangat bermanfaat
bagi remaja karena pendidikan seks pendidikan seks dianggap dapat menjawab semua kebutuhan remaja kaitannya dalam membantu mengatasi semua persoalan seks remaja. Dengan demikian dapat disimpulkan bahwa pandangan seseorang khususnya remaja tentang pendidikan seks adalah bermacam-macam Dari bermacam-macam pandangan remaja tentang pendidikan seks tentunya setiap orang mempunyai pandangannya masing-masing dimana pandangannya bisa berbeda-beda. Perbedaan persepsi tergantung dari latar belakang, pengalaman dan informasi yang diterima oleh orang yang bersangkutan. Hal ini sesuai dengan pendapat Bimo Walgito (2003: 46) menyatakan bahwa, ada dua faktor yang

Mempengaruhi persepsi antara lain: faktor internal dan faktor eksternal. Faktor internal adalah faktor yang ada dalam individu itu sendiri, seperti perasaan, pengalaman, kemampuan berfikir, dan kerangka acuan. Sedangkan faktor eksternal adalah faktor stimulus itu sendiri dan mereka. Remaja mengartikan pendidikan seks sebagai suatu proses transfer pengetahuan tentang seks denan tujuan untuk membekali individu dengan pengetahuan tentang seks sehingga mereka dapat mengetahui segala sesuatu yang berhubungan dengan seks.

Pendidikan seks dapat dari diperoleh dari tiga unsur lingkungan pendidikan seperti seperti keluarga, sekolah maupun masyarakat. Sumber pendidikan seks yang pertama dan utama adalah berasal dari lingkungan keluarga, khususnya orang tua. Hal ini dikarenakan orang tua sebagai pihak yang paling bertanggung jawab terhadap keselamatan anaknya dalam menjalani tahapantahapan perkembangan baik fisik, emosional, seksual, sosial dan lain-lain. Tanggung jawab orang tua tidak hanya mencakup atau terbatasi pada kebutuhan materi saja tetapi sesungguhnya mencakup juga pada seluruh aspek kehidupan anaknya, termasuk didalamnya aspek pendidikan seks.

Namun demikian pada kenyataannya remaja justru sering memperoleh berbagai informasi dan pengetahuan tentang seks dari berbagai media massa baik media cetak sepeti koran, majalah, dan buku maupun media elektronik seperti televisi dan internet dan teman sebaya atau peer group. Pendidikan seks banyak diperoleh oleh remaja dari sumber lain di luar lingkungan keluarga seperti media massa dan teman sebaya karena pada dasarnya mereka tidak mendapatkan pendidikan seks dari orang tuanya.

Anggapan tabu orang tua untuk membicarakan segala sesuatu yang berkaitan dengan seks menjadi alasan yang mendasari 
mereka untuk tidak memberikan pendidikan seks internet terkadang kebenarannya masih bagi remaja. Hal tersebut yang akhirnya dipertanyakan.

mendorong remaja untuk mencari berbagai Media massa baik cetak maupun elektronik informasi dan pengetahuan seks dari sumber- menggantikan posisi orang tua sebagai institusi sumber lain yang dapat menjawab segala primer dalam hal pendidikan seks. Media massa kebutuhan remaja akan seks. Sumber-sumber lain telah menggeser fungsi dan peran orang tua tersebut adalah media massa dan teman sebaya sebagaimana mestinya sebagai pihak yang paling atau peer group. Pengaruh media massa dan peer bertanggung jawab dalam memberikan group ini tidak terlepas dari infiltrasi globalisasi pendidikan seks. Hubungan secara langsung antar informasi dan budaya yang juga menyerang perorangan telah tergantikan oleh sebuah benda kehidupan remaja. Hal ini sesuai dengan seperti media massa. Nampaknya sistem referensi pernyataan Panut Panuju dalam I Nyoman Sukma telah mengalami pergeseran dari tradisional ke Arida, 2005: 41) yang mengatakan, "Remaja modern, dari tatap muka atau face to face ke yang sedang dalam periode ingin tahu dan ingin benda atau media. remaja menggunakan media mencoba akan melihat apa yang akan dilihat dan massa sebagai sumber pendidikan seks karena didengarnya dari media massa karena pada pada umumnya mereka tidak mendapatkan dari umumnya mereka belum berpendidikan seks lingkungan keluarga dan sekolah. Hal ini dapat secara lengkap dari orang tuanya".

Media massa digunakan sebagai sumber untuk memperoleh pendidikan seks. Remaja lebih sering memperoleh berbagai informasi dan pengetahuan tentang seks dari media massa baik media cetak seperti koran, majalah, dan buku maupun media elektronik seperti televisi dan internet serta teman sebaya atau peer group karena pada dasarnya mereka tidak diberi pendidikan seks dari lingkungan keluarga, khususnya orang tua. Alasan remaja sering menggunakan media massa sebagai sumber pendidikan seks dikarenakan kemudahan dalam mengaksesnya. Pengetahuan seputar seks lebih mudah diperoleh dari media massa dibandingkan dengan sumber-sumber lainnya.

Sumber pendidikan seks yang berasal dari media massa selain dipandang mempunyai berbagai kemudahan untuk diakses, keterbukaan dalam memberikan berbagai informasi dan pengetahuan tentang seks bagi remaja ternyata juga dipandang sebagai sumber yang paling memberikan kemudahan bagi remaja untuk memahami berbagai pengetahuan yang berkaitan dengan seks. Penyajian informasi dan pengetahuan di artikel atau rubrik dalam media massa yang seringkali dinilai blak-blakan atau secara gamblang mampu memberikan pemahaman tersendiri bagi remaja. Alasan inilah yang menjadikan media massa menjadi sumber yang sering digunakan oleh remaja untuk memperoleh pendidikan seks. Meskipun media dinilai lebih terbuka dan jelas dalam mengulas setiap informasi dan pengetahuan yang berkaitan dengan seks akan tetapi remaja juga memandang kalau sumber dari media massa khususnya dikatakan sumber pendidikan seks yang utama seperti keluarga dan sekolah sudah tergantikan oleh sumber pendidikan seks lainnya yang mungkin saja bisa kurang dipertanggungjawabkan kebenaran informasinya. Hal ini sesuai dengan teori aksi bahwa tindakan manusia muncul dari kesadarannya sendiri sebagai subjek dan dari situasi eksternal dalam posisi sebagai objek. Sebagai subjek manusia bertindak atau berperilaku untuk mencapai tujuan-tujuan tertentu. Manusia memilih dan mengevaluasi terhadap tindakan yang akan, sedang dan telah dilakukannya (Ritzer, 2004: 46). Remaja karena tidak mendapatkan pendidikan seks dari lingkungan keluarga dan sekolah maka akan mencari sendiri dari sumber-sumber lain di luar lingkungan tersebut, dalam hal ini adalah dari media massa dan peer group. Media massa menjadi pilihan bagi remaja sebagai sumber pendidikan seks karena media massa dinilai dapat memberikan informasi dan pengetahuan tentang seks jauh lebih terbuka dan transparan dibandingkan dengan sumber pendidikan seks lainnya khususnya dari lingkungan keluarga seperti orang tua. Media massa mampu menyajikan berbagai informasi dan pengetahuan seputar seks secara lengkap, jelas dan transparan. Terkadang media massa berusaha mengemas informasi dan pengetahuan seks semenarik mungkin sehingga menyebabkan remaja tertarik untuk membacanya. Tidak jarang pula banyak dijumpai media massa yang berani mengungkap segala hal yang ada kaitannya dengan seks secara vulgar atau blak-blakan. Ulasan informasi seperti inilah yang biasanya disukai oleh para remaja karena mereka tidak terlalu senang dengan hal yang sifatnya setengah-setengah karena dapat 
menimbulkan rasa penasaran. Media massa melibatkan hubungan antar subjektif dan dipandang oleh remaja sebagai sumber pembentukkan makna (Van Maanen dalam pendidikan seks yang paling dapat memberikan Sutopo, 2002: 30). Perasaan tabu dan rasa banyak pemahaman mengenai informasi dan bersalah yang masih dimiliki oleh masyarakat, pengetahuan tentang seks dibandingkan dengan khususnya orang tua atau pendidik pada saat sumber pendidikan seks yang lainnya. Alasan membicarakan seks sudah saatnya mulai lain media massa lebih disukai oleh remaja dihilangkan, dibongkar dan ditempatkan dalam sebagai sumber pendidikan seks karena sebagian keadaan sewajarnya. Berbicara soal seks besar dari mereka tidak mendapatkan pendidikan sebenarnya tidak hanya membicarakan tentang seks dari orang tuanya. Para orang tua tidak hubungan seksual atau hal-hal yang negatif memberikan pendidikan seks pada anak mereka seperti anggapan masyarakat selama ini. Namun karena berpendapat kalau membicarakan segala berbicara tentang seks artinya kita berbicara sesuatu yang berkaitan dengan seks adalah hal tentang kesehatan reproduksi, anatomi, fisiologi yang tabu. Sikap mentabukan pembicaraan organ reproduksi, penyakit menular seka dan mengenai seks yang dianut oleh sebagian lain-lain. Seks itu sangat luas sekali dimensinya masyarakat kita membuat permasalahan mencakup dimensi fisik, mental maupun sosial. mengenai seks menjadi sulit untuk dipahami. Oleh karena itu membicarakan tentang seks Tidak jarang orang tua cenderung menutup- bukanlah hal yang tabu.

nutupi ketika anaknya bertanya mengenai Seks merupakan bahan pembicaraan yang masalah seks. Maka ketika remaja gagal peka. Di satu pihak ia sangat dibutuhkan, tetapi menerima informasi tentang seks dari orang tua di pihak lain orang berusaha menutup-nutupinya. dan guru, mereka akan mencarinya dari sumber- Persoalan seks tidak perlu ditutup-tutupi, namun sumber lain seperti media massa dan teman juga tidak lantas dibicarakan secara terbuka. Seks sebaya.

Keterbatasan serta kurang luasnya wawasan masyarakat tentang seks sehingga menimbulkan kekeliruan masyarakat kita di dalam mengartikan kata seks yaitu hanya disempitkan pada hubungan seksual semata. Hal seperti ini yang akhirnya menimbulkan konsep dan cara pandang tersendiri bagi mereka. Pada akhirnya masyarakat menilai seks sebagai hal yang tidak patut atau lumrah untuk dibuka atau diperbincangkan di ranah publik. Membicarakan seks hanya boleh dilakukan bagi mereka yang sudah menikah atau pasangan suami istri. Pandangan bahwa seks adalah sesuatu yang saru, negatif dan tabu apabila diperbincangan secara umum dan terbuka akhirnya terpatri di benak masyarakat kita. Hal semacam inilah yang menimbulkan adanya budaya tabu mengenai seks. Budaya merupakan pengetahuan yang diperoleh seseorang dan bereksplorasi an diri, nilai-nilai, digunakan untuk menginterpretasikan identitas. Di samping itu remaja juga memiliki pengalaman yang menghasilkan perilaku dorongan rasa ingin tahu yang sangat besar (Spradley dalam Sutopo, 2002: 30). Budaya yang terhadap segala sesuatu, terlebih segala hal yang berbeda, melatih orang secara berbeda pula di menyangkut keadaan dirinya. Salah satu rasa dalam menangkap makna persepsi (Knobler ingin tahu remaja yakni terhadap hal yang dalam Sutopo, 2002: 30), karena kebudayaan berkaitan dengan seks. Umumnya remaja menilai merupakan cara khusus dalam membentuk seks sebagai sesuatu hal yang sifatnya eksklusif pikiran dan pandangan manusia (Cohen dalam artinya selalu ada rasa ingin tahu yang besar Sutopo, 2002: 30). Kondisi kehidupan budaya terhadap seks. Secara alamiah remaja menjadi seseorang sangat mempengaruhi persepsi dan sangat ingin tahu mengenai seks bersamaan penciptaan makna pada setiap peristiwa sosial, dengan mulai bekerjanya fungsi organ reproduksi yang dalam setiap kehidupan sosial selalu dan sistem hormonalnya. Tidaklah 
mengherankan apabila rasa ketertarikan dan penasaran remaja terhadap segala hal yang berkaitan dengan seks menjadi sangat besar.

\section{KESIMPULAN}

Berdasarkan hasil pembahasan di atas maka dapat disimpulkan, bahwa:

Pertama, Pendidikan seks dalam pandangan remaja sebagai sesuatu yang penting, bernilai positif, serta bermanfaat bagi mereka dalam membantu persoalan hidup remaja. Melalui pendidikan seks remaja mampu mengarahkan perilaku seksualnya agar tidak menyimpang dari norma yang ada serta dapat terhindar dari hal-hal yang negatif. Dengan kata lain remaja memandang pendidikan seks sebagai alat untuk mencegah terjadinya penyalahgunaan seks. Remaja menganggap pendidikan seks mampu menjawab keingintahuan dan rasa penasaran mereka akan segala hal yang berkaitan dengan seks. Oleh karena itu remaja menganggap pendidikan seks sebagai suatu kebutuhan dan mereka tidak menabukannya. Kedua, Sumber pendidikan seks yang digunakan oleh remaja adalah media massa baik media cetak seperti koran, majalah, dan buku maupun media elektronik seperti televisi dan internet serta teman sebaya atau peer group. Remaja banyak mendapatkan informasi dan pengetahuan seks dari media massa dan teman sebaya karena sumber pendidikan tersebut dapat memberikan informasi dan pengetahuan secara terbuka dan transparan pada mereka. Pendidikan seks justru tidak didapat remaja dari lingkungan keluarga ataupun sekolah. Ketiga, Pengetahuan seputar seks yang dicari dan dibutuhkan oleh remaja adalah pengetahuan tentang HIV AIDS, menstruasi, penyakit kelamin, dampak atau resiko melakukan seks bebas, proses reproduksi atau hubungan seks dan gaya pacaran sehat.

\section{DAFTAR PUSTAKA}

Abdullah Nashih Ulwan dan Hassan Hathout. 1992. Pendidikan Anak Menurut Islam Pendidikan Seks. Bandung : PT Remaja Rosdakarya.

Alimatul Qibtiyah. 2006. Paradigma Pendidikan Seksualitas. Penerbit Kurnia Kalam Semesta.

Bambang Mulyono. Y. 1993. Mengatasi Kenakalan Remaja. Yogyakarta: Yayasan Andi . 1997. Pendekatan
Analisis Kenakalan Remaja dan Pendekatannya. Yogyakarta: Kanisius

Bimo Walgito. 1997. Pengantar Psikologi Umum. Yogyakarta: Andi Offset. 2005. Psikologi Sosial (Suatu Pengantar). Yogyakarta : Andi Offset. Bgd. Armaidi Tanjung. 2007. Free Sex No Nikah Yes. Jakarta : Amzah.

Burhan Bungin. 2001. Erotika Media Massa. Surakarta: Universitas Muhammadiyah Surakarta. 2007. Penelitian Kualitatif. Jakarta: Kencana Prenada Media Group.

Burhanuddin Salam. 2005. Pengantar Filsafat. Jakarta : Bumi Akasara Deddy Mulyana \& Jalaludin Rakhmat. 1998. Komunikasi Antarbudaya. Bandung: Remaja Rosdakarya. Didik Hermawan. 2007. Ngerumpi Sex Yuk. Solo : Smart Media.

Dimyati Mahmud. 1990. Psikologi Pendidikan: suatu Pendekatan Terapan. Yogyakarta: BPFEE

Elizabeth Hurlock. 2000. Psikologi Perkembangan. Jakarta : PT Erlangga. George Ritzer. 2004. Sosiologi Ilmu Pengetahuan Berparadigma Ganda. Jakarta: PT RajaGrafindo Persada

Hikmat Budiman. 2002. Lubang Hitam Kebudayaan. Yogyakarta: Kanisius.

Idi Subandi Ibrahim. 1997. Estacy Gaya Hidup: Kebudayaan Pop dalam Masyarakat Komoditas Indonesia. Bandung: Penerbit Mizan.

I Nyoman Sukma Arida, dkk. 2005. Seks dan Kehamilan Pranikah. Yogyakarta: Iniversitas Yogyakarta.

Abdullah. 2006. Konstruksi dan Reproduksi Kebudayaan. Yogyakarta: Pustaka Pelajar.

Jalaludin Rakhmat. 2007. Psikologi Komunikasi. Bandung : PT Remaja Rosdakarya

Kartini Kartono. 1990. Psikologi Anak (Psikologi Perkembangan). Bandung : Mandar Maju.

Lexy. J. Moleong. 2006. Metodologi Penelitian Kualitatif. Bandung: PT. Remaja.] Marzuki Umur Sa'abah. 2001. Perilaku Seks Menyimpang dan Seksualitas Kontemporer Umat Islam. Jogjakarta : UII Press.

Moh. Nasir. 1988. Metode Penelitian. Jakarta: Ghalia Indonesia.

Monks F.J, dkk. 1991. Psikologi Perkembangan Pengantar Dalam Berbagai Bagiannya. 
Volume 3 Nomor 2, Halaman 1-77, Juli-Desember 2018

RISTEKDIK / Jurnal Bimbingan dan Konseling

P-ISSN: 2527-4244, E-ISSN : 2541-206X 